\title{
Sodium content in meat products: suitability to labeling and the voluntary agreements
}

\section{Conteúdo de sódio em produtos cárneos: adequação à rotulagem e aos acordos voluntários}

\author{
Valcenir Júnior Mendes Furlan ${ }^{1 *}$; Kauan Trindade Mello2; Fábio Zacouteguy Ugalde ${ }^{3}$; \\ João Pedro da Silva Cunha²; Rafaela Garay Pires ${ }^{4}$; Graciela Salete Centenaro ${ }^{5}$
}

\section{Highlights}

Some industries do not standardize the content of ingredients in their formulations.

Only voluntary agreements do not guarantee the total adequacy of sodium level.

Italian salami was the meat derivative with the highest average sodium content.

\begin{abstract}
This study was undertaken to evaluate the sodium concentration in meat products, to ascertain their appropriateness for labels and agreements set up between the Health Ministry and the Brazilian Association of Food Industries. A total of 96 meat derivative samples (italian salami, chicken pate, cooked ham, ham, sausage, bologna, tuscan sausage and smoked mixed sausage) were collected from different brands and batches. Using flame emission spectroscopy, the samples were analyzed for sodium levels based on the official methodology. It was observed that $46.9 \%$ of the companies showed values in nutritional labeling to be noncompliant with the Brazilian legislation. In fact, $31.2 \%$ of the brands assessed failed to satisfy the sodium reduction target decided upon for 2017. The italian salami was the product with the higher sodium

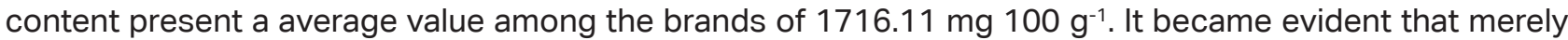
implementing voluntary agreements had failed to provide total adequacy in the sodium content of the meat products. There is also great need for the industries to be more engaged in finding substitutes to minimize the sodium levels in the foods, without inducing significant alterations in the physicochemical, microbiological and technological features of the products, apart from the higher inspection by the government agencies in terms of agreement compliance and population awareness.

Key words: Flame photometry. Hypertension. Legislation. Meat derivatives. Salt.

1 Prof., PhD., Food Science and Technology Course, Federal University of Pampa, UNIPAMPA, Itaqui, RS, Brazil. E-mail: juniorfurlan@yahoo.com.br

2 Undergraduate Students, Food Science and Technology Course, UNIPAMPA, Itaqui, RS, Brazil. E-mail: kauan_1993@ hotmail.com; joaopedrocunhalr@gmail.com

3 PhD Student of Graduate Program in Food Science, Federal University of Santa Catarina, UFSC, Florianópolis, SC, Brazil. E-mail: fabiozacouteguy@gmail.com

4 Undergraduate Student, Nutrition course, UNIPAMPA, Itaqui, RS, Brazil. E-mail: rafagaraypires@gmail.com

${ }_{5}$ Prof., PhD., Nutrition and Food Science and Technology Courses, UNIPAMPA, Itaqui, RS, Brazil. E-mail: gracielacentenaro@unipampa.edu.br

* Author for correspondence
\end{abstract}

Received: Sept. 25, 2020 - Approved: Nov. 18, 2020 


\section{Resumo}

O objetivo deste trabalho foi determinar a concentração de sódio em produtos cárneos a fim de verificar sua adequação aos rótulos e aos acordos de redução estabelecidos entre Ministério da Saúde e Associação Brasileira das Indústrias da Alimentação. Foram coletadas 96 amostras de derivados cárneos (salame tipo italiano, patê de frango, presunto cozido, apresuntado, salsicha, mortadela, linguiça toscana e linguiça mista defumada) de diferentes marcas e lotes. As amostras foram analisadas quanto ao conteúdo de sódio, empregando espectroscopia de emissão de chama, conforme metodologia oficial. Foi observado que $46,9 \%$ das empresas estavam com os valores expressos na rotulagem nutricional em desacordo com a legislação brasileira e 31,2\% das marcas avaliadas não cumpriram a meta para redução de sódio acordada para 2017. O salame tipo italiano foi o produto que apresentou maior conteúdo de sódio, com valor médio entre as marcas de 1716,11 mg $100 \mathrm{~g}^{-1}$. Verificou-se que somente a implantação de acordos voluntários não resulta em uma adequação total no teor de sódio nos produtos cárneos, bem como, faz-se necessário um maior engajamento das indústrias em encontrar alternativas para a redução de sódio nos alimentos sem que haja alterações significativas nos aspectos físico-químicos, microbiológicos e tecnológicos dos produtos, além de uma maior fiscalização dos órgãos governamentais referente ao cumprimento dos acordos e a conscientização da população.

Palavras-chave: Derivados cárneos. Espectrometria de chama. Hipertensão. Legislação. Sal.

\section{Introduction}

Globalization and urbanization are the factors which induced the consumption of meat derivatives due to the change in the pattern of food intake that has occurred worldwide as well as in Brazil. These factors triggered a spike in the population growth in the urban regions, resulting in a rise in the number of stores and supermarkets, which promote accessibility to pre-cooked and savory foods. Besides, the intake of pre-cooked meals and fast foods is in some way related to minimizing the time involved in preparing traditional meals (Moratoya, Carvalhaes, Wander, \& Almeida, 2013), one of the reasons for the increased salt consumption via food. Furthermore, the excessive intake of sodium present in table salt is also linked to diet alterations in the population as such, activated by the intake of processed foods (Buzzo et al., 2014). Canned, sausages, cheeses and snacks rank high among the sodium-rich industrialized products (Costa \& Machado, 2010).

Sodium is an essential mineral component present in salt or sodium chloride $(\mathrm{NaCl})$. This mineral, when consumed in moderate quantities, facilitates the proper performance of the organism (Buzzo et al., 2014). Large scale usage of sodium chloride $(\mathrm{NaCl})$ in meat derivatives is popular primarily because of its flavor-enhancing capacity; however, it also retards microbial growth, acts as a preservative, and raises the ionic strength of the medium, permitting water absorption by the myofibrillar proteins and solubilization (Pardi, Santos, Souza, \& Pardi, 2001).

Sodium intake, in the recommended quantity, is vital for the organism to function well because this essential nutrient governs the maintenance of the plasma volume, cellular 
function and nerve impulse transmission. However, excessive sodium intake is related to a heightened possibility of developing chronic non-communicable diseases (NCDs) such as arterial hypertension and cardiovascular and cerebrovascular diseases. Similarly, decreased sodium intake results in lowering the blood pressure in adults and children (Aburto et al., 2013).

Data from the Health Ministry, it was found that an average of $24.7 \%$ of the adult population living in the Brazilian capitals cited a medical diagnosis of arterial hypertension in 2018. Excessive sodium consumption may have played a crucial role in the rise in that number (Ministério da Saúde [MS], 2018b).

In light of the concern to decrease the sodium intake by the Brazilian population, the National Sodium Reduction Plan for Processed Foods was initiated. Based on voluntary agreement with the food production sector, biannual goals were decided upon, with the goal of minimizing the sodium concentration in different food categories. In 2011, the first commitment term was signed between the Ministry of Health and the Brazilian Association of Food Industries; in November 2013, the fourth commitment term was signed for the category, which included dairy products, meals (soups) and meat products (MS, 2013).

Therefore, in view of the escalating intake of meat derivatives by the Brazilian population, resulting from an alteration in the food consumption pattern and the subsequent backlash of pathologies resulting from excessive sodium consumption, studies are required to confirm the salt content in foods, in addition to adequacy in terms of voluntary agreements. Hence, this work was undertaken to establish the sodium content in a variety of meat product brands available in the retail market on the western border of Rio Grande do Sul-Brazil, as well as to ascertain their adequacy against the agreed limits whit values declared on labels.

\section{Material and Methods}

The meat product samples were periodically collected from commercial establishments present in the western border region of the Rio Grande do Sul, Brazil. After identification, they were transported in thermal boxes and stored at $-18{ }^{\circ} \mathrm{C}$ until they were analyzed. Overall, eight meat products (italian salami, chicken pate, cooked ham, ham, frankfurter, mortadella, tuscan sausage and smoked mixed sausage) from four different brands $(A, B, C$ and $D)$, were collected, totalizing 32 brands. These were the top in sales in the Brazilian market. From each brand, three different lots were evaluated (L1, L2 and L3); thus 96 samples were analyzed in quadruplicate $(n=384)$ as shown in Figure 1. 

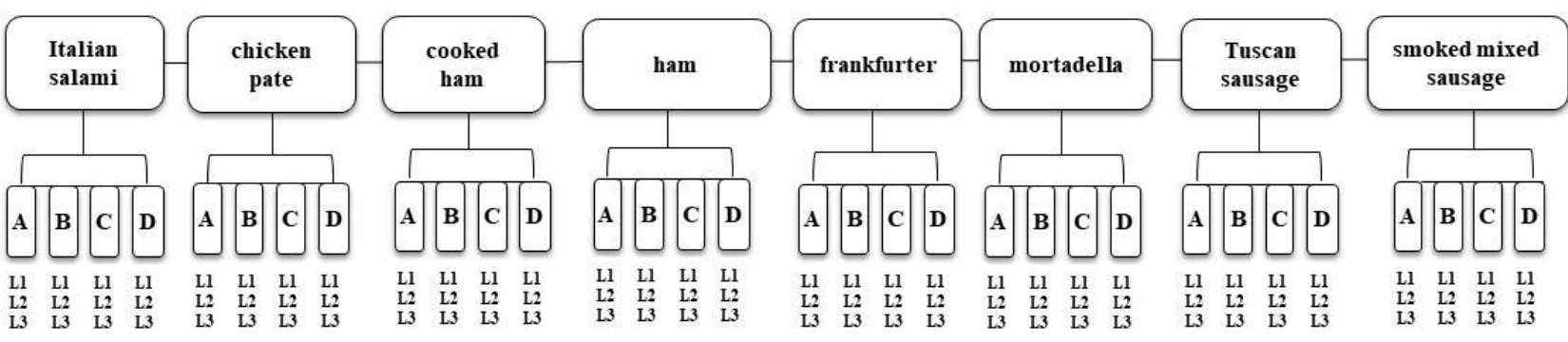

Figure 1. General scheme of sampling performed for analytical determinations.

Then sodium was quantified employing the flame emission spectroscopy. After weighing each sample $(4 \mathrm{~g})$ dry digestion of the organic matter was performed in a muffle at $525{ }^{\circ} \mathrm{C}$ until the material was completely combusted. The ashes thus attained were solubilized using nitric acid. The filtrate was collected in a volumetric flask and after completing the volume, it was read in a flame photometer (Digimed, DM-62, São Paulo, Brazil), based on the official methodology prescribed by the Ministry of Agriculture, Livestock and Supply (Ministério da Agricultura, Pecuária e Abastecimento [MAPA], 2018).

The sodium content obtained experimentally was assessed for adequacy to the goal set up in the fourth Term of Commitment. The results were compared to the values mentioned on the label of each product and then subjected to analysis of variance (ANOVA). The significant differences were determined using the comparison of means test (Tukey) at the $5 \%$ level of significance. The Kolmogorov-Smirnov and Cochran tests were performed prior, to confirm the data normality and the similarity of their variances, respectively (Triola, 2008).

\section{Results and Discussion}

Table 1 lists the average sodium concentration for each product brand analyzed. The manufacturers values stated on the labels and the sodium reduction target can also be verified in accordance to the fourth Term of Commitment. 
Table 1

Sodium concentration in italian salami, chicken pate, cooked ham, ham, frankfurter, bologna, tuscan sausage and smoked mixed sausage $(n=384)$

\begin{tabular}{|c|c|c|c|c|}
\hline meat product & brand & $\begin{array}{l}\text { *sodium content by } \\
\left.\text { brand (mg } 100 \mathrm{~g}^{-1}\right)\end{array}$ & $\begin{array}{l}\text { sodium declared on } \\
\text { the label }\left(\mathrm{mg} 100 \mathrm{~g} \mathrm{~g}^{-1}\right)\end{array}$ & 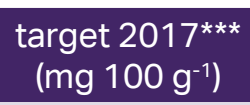 \\
\hline \multirow{4}{*}{ italian salami } & $A$ & $1608.02 \pm 101.13$ & 2025.00 & \\
\hline & B & $1875.80 \pm 57.31$ & 2050.00 & \\
\hline & $\mathrm{C}$ & $1763.67 \pm 133.72^{* *}$ & 1482.50 & \\
\hline & $\mathrm{D}$ & $1616.95 \pm 83.45$ & 2062.50 & \\
\hline \multirow{4}{*}{ chicken pate } & $A$ & $956.26 \pm 56.53$ & 1000.00 & \multirow{4}{*}{-} \\
\hline & B & $968.43 \pm 73.39$ & 1230.00 & \\
\hline & C & $846.28 \pm 36.69$ & 1100.00 & \\
\hline & $\mathrm{D}$ & $957.32 \pm 34.88$ & 1110.00 & \\
\hline \multirow{4}{*}{ cooked ham } & $A$ & $1172.45 \pm 189.62^{* *}$ & 1000.00 & \multirow{4}{*}{1160.00} \\
\hline & B & $1031.17 \pm 76.37$ & 1160.00 & \\
\hline & C & $1328.37 \pm 50.39 * *$ & 935.00 & \\
\hline & D & $1331.36 \pm 29.30^{* *}$ & 975.00 & \\
\hline \multirow{4}{*}{ ham } & A & $1126.36 \pm 177,05^{* *}$ & 800.00 & \multirow{4}{*}{1160.00} \\
\hline & B & $1522.56 \pm 192,77^{* *}$ & 1180.00 & \\
\hline & C & $1443.79 \pm 125.39^{* *}$ & 1255.00 & \\
\hline & $\mathrm{D}$ & $1366.90 \pm 41.33^{* *}$ & 1020.00 & \\
\hline \multirow{4}{*}{ frankfurter } & $A$ & $1026.35 \pm 135.13$ & 1054.00 & \multirow{4}{*}{1120.00} \\
\hline & B & $948.01 \pm 152.15$ & 1140.00 & \\
\hline & C & $814.97 \pm 43,14$ & 1200.00 & \\
\hline & $\mathrm{D}$ & $1080.45 \pm 109,21$ & 1130.00 & \\
\hline \multirow{4}{*}{ mortadella } & $A$ & $1062.94 \pm 58.24$ & 1127.50 & \multirow{4}{*}{1180.00} \\
\hline & B & $1020.75 \pm 158.24^{* *}$ & 495.00 & \\
\hline & C & $930.54 \pm 37.69$ & 1027.50 & \\
\hline & $\mathrm{D}$ & $850.33 \pm 40.72$ & 1180.00 & \\
\hline \multirow{4}{*}{ tuscan sausage } & $A$ & $993.90 \pm 92.06^{* *}$ & 880.00 & \multirow{4}{*}{970.00} \\
\hline & $\mathrm{B}$ & $955.89 \pm 118.56$ & 1356.00 & \\
\hline & C & $929.67 \pm 79.01^{* *}$ & 850.00 & \\
\hline & $\mathrm{D}$ & $886.56 \pm 67.88^{* *}$ & 770.00 & \\
\hline \multirow{4}{*}{$\begin{array}{l}\text { smoked mixed } \\
\text { sausage }\end{array}$} & $A$ & $1879.39 \pm 271.64^{* *}$ & 1200.00 & \multirow{4}{*}{1210.00} \\
\hline & B & $1634.12 \pm 228.04^{* *}$ & 1310.00 & \\
\hline & C & $994.34 \pm 76.55$ & 1000.00 & \\
\hline & $\mathrm{D}$ & $1751.14 \pm 100.52$ & 1912.00 & \\
\hline
\end{tabular}

Mean values \pm standard deviation ( 3 lots analized in quadruplicate $=12$ replicates). ${ }^{*}$ Sodium content higher than expressed on the label. ***Target according to the fourth Term of Commitment. 
As the statistical analysis revealed that the results were normal and homoscedastic the ANOVA was done with three levels per treatment (three different lots for each brand). Next, the Tukey test was done to compare the means. The " $C$ " marks of the italian salami, " $B$ " of the frankfurter, as well as the " $A$ " and " $B$ " of the smoked mixed sausage revealed significant differences $(p<0.05)$ between the batches. This indicates of the lack of care in standardizing the quantities of ingredients added during product manufacture. On the other hand, the same product can reveal differences, which are caused by the variations in the raw materials, formulations and manufacturing processes employed by the industries (Zanardi, Ghidini, Conter, \& laneri, 2010).
The Table 1 show that 14 of the 32 brands surveyed possess a higher sodium content than that stated on the label. However, according to RDC 360/2003, an error margin of more or less $20 \%$ points is permissible, in terms of the concentrations of nutrient declared on the label (Resolução RDC n 360, 2003). From this, the percentage of sodium determined experimentally was compared with that mentioned on the label. This study revealed that $46.9 \%$ of the meat product brands failed to comply with the tolerance levels (+/- 20\%) permitted by Brazilian legislation (Figures 2 and 3).

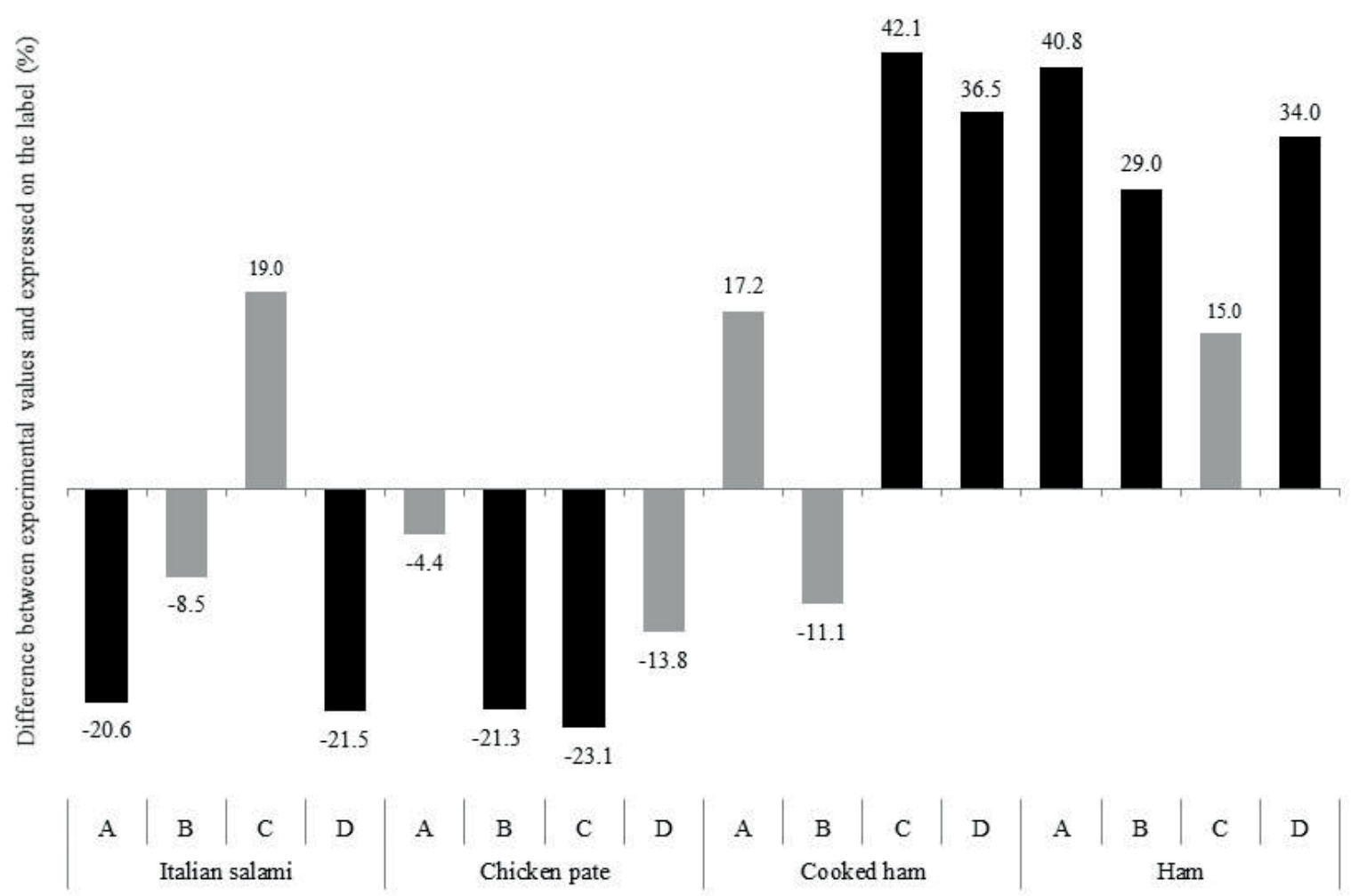

Figure 2. Variation between the sodium content determined experimentally and the content expressed on the label.

In compliance whit RDC 360/2003

In non-compliance whit RDC 360/2003 
The sodium content of 17 processed foods samples aimed at children and adolescents was reported and 13 samples analyzed had nutritional labeling which did not concur with the Brazilian regulation (Resolução RDC $n^{\circ} 360,2003$ ) of the National Health Surveillance Agency (Ribeiro, Ribeiro, Vasconcelos, Andrade, \& Stamford, 2013).

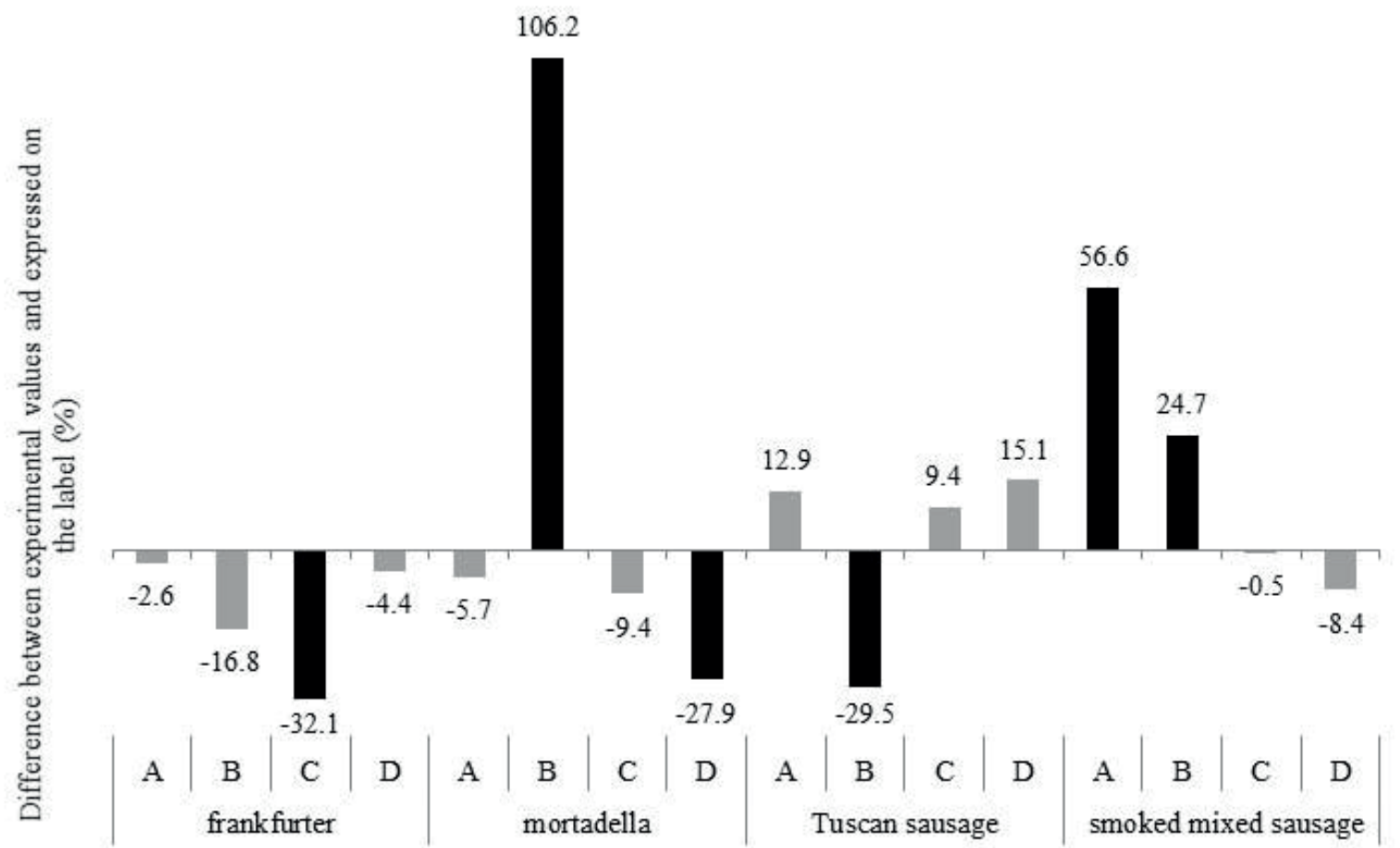

Figure 3. Variation between the sodium content determined experimentally and the content expressed on the label.

In compliance whit RDC 360/2003

— In non-compliance whit RDC 360/2003

The "B" mark, with reference to the mortadella, revealed a difference of $106.2 \%$ between the analyzed value and the value declared on the label (Figure 3). Thus, the consumer is ingesting $1020.75 \mathrm{mg} 100 \mathrm{~g}^{-1}$ rather than taking in a maximum of $495 \mathrm{mg}$ $100 \mathrm{~g}^{-1}$ of sodium as stated on the label. It is suggested that manufacturers are inaccurately marketing their meat products, ignoring the consumer protection code. Therefore, the population is purchase food products whose quality and safety standards are suspect, implying that the consumer is unaware of the quantity of the nutrients present in them. Thus, in keeping with the consumer protection code, it is only fair that the product labels must list the accurate and appropriate information, giving the specific quantity, composition and quality. They must also list the possible risks which can arise on consumption of a particular product (Lei n. 8.078, 1990). This means, it is the duty of the food companies to comply with these specifications. 
According to the fourth Term of Commitment (MS, 2013), the signatory industries of the agreement should achieve in 2017 the maximum sodium content (mg $100 \mathrm{~g}^{-1}$ ) stipulated to: 1160 for ham, 1120 for frankfurter, 1180 for mortadella stored under refrigeration, 970 for fresh sausage and 1210 for cooked sausage refrigerated.

The category of salamis has been excluded because this product involves technological barriers for sodium mitigation, connected to the antimicrobial activity and product texture (MS, 2013). The agreement also excluded the pate category. Although these categories were excluded from the term of commitment, the present study compared the results obtained here with those reported in other studies.

Italian salami formulations were produced in which the sodium chloride was partially substituted by potassium lactate. The concentration of $1.5 \%$ of the lactate salt showed an antioxidant and buffering ability while the lower concentration (potassium lactate $0.75 \%)$ favored the dehydration process and the growth of lactic bacteria (Cichoski, Zis, \& Franceschetto, 2009). Gelinski et al. (2015) produced chicken pate with 5.3\% less sodium concentration (882.38 mg $100 \mathrm{~g}^{-1}$ ) than the value recorded in the present study

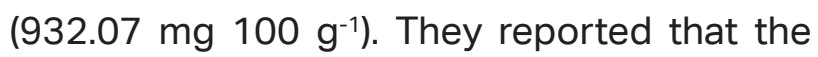
quantity of sodium added did not alter the sensorial acceptance of the final products.

The " $\mathrm{A}$ " mark of the tuscan sausage crossed the maximum recommended limit mentioned in the agreement (Table 1). Besides, $75.0 \%$ of the brands assessed for cooked ham ( $A, C$ and $D)$, ham ( $B, C$ and $D)$ and smoked mixed sausage $(A, B$ and $D)$ showed the sodium content to exceed the limit established by the Ministry of Health and ABIA (MS, 2013).
The smoked mixed sausage (" $\mathrm{A}$ " mark) revealed $55.3 \%$ sodium concentration more than the stipulated level. This is evidence of the lack of commitment shown by some companies to the agreement they had signed. One of the reasons cited for the non-compliance of the limit set by the productive sector is that the lowered sodium would imply a sensory adaptation on the part of the population, and that such a reduction should be slow and gradual; also, many technological challenges are involved, becouse that sodium plays a crucial role in food safety. Furthermore, it is not mandatory to adhere to the agreement, and any such compliance occurs only according to the disposition of those involved (Cardin, 2014). That's why punishments are not meted out to companies that disregard the agreement; however, the Ministry of Health and National Health Surveillance Agency are responsible to monitor their compliance, so that the companies adapt to the goals established.

The Ministry of Health published the monitoring results for sodium content for the year 2017 for several products, which showed that $87.5 \%$ of the samples met the goals of the Terms of Commitment. However, there was a decrease in the percentage of products that were in accordance with the targets in relation to the monitoring of previous years, and in some cases a proportional increase in the sodium content (MS, 2018a).

Some countries, namely the United Kingdom, the United States and Canada are now reporting a gradual reduction in the sodium levels in foods due to voluntary agreements. Argentina, South Africa and the Netherlands too reported decreases in sodium concentrations, butthis objectivewasachieved due to the mandatory targets set by efficient bodies in each nation (Webster, Trieu, Dunford, 
\& Hawkes, 2014). In the United Kingdom, the Food Standards Agency recommended a food packaging approach based on the traffic lights color code, which specifies the quantity in grams of fat, saturated fat, sugar and salt in the food product. The colors green yellow and red indicate low, medium and high concentrations, respectively (Wyness, Butriss, \& Stanner, 2011). In Brazil, the National Health Surveillance Agency, RDC 24/2010, defines "food with a high amount of sodium is one that has in its composition an amount equal to or greater than $400 \mathrm{mg}$ of sodium per $100 \mathrm{~g}$ or $100 \mathrm{~mL}$ as it is exposed for sale" (Resolução $\left.R D C n^{\circ} 24,2010\right)$. In light of this classification, all the products analyzed in the present study are high in sodium content because the results were in the range of 814.97 to $1879.39 \mathrm{mg} 100$ $\mathrm{g}^{-1}$ (Table 1).

The italian salami was the product which revealed the highest sodium concentration, averaging $1716.11 \mathrm{mg} 100 \mathrm{~g}^{-1}$ between the brands. To standardize the formulation of this type of product researchers established an $\mathrm{NaCl}$ level of roughly $3.0 \%$, equivalent to 1180 mg of sodium $100 \mathrm{~g}^{-1}$ (Cichoski et al., 2009). Given this information, the brands analyzed in this study would be found to add $45.4 \%$ more sodium on an average than the stipulated concentration.

Research shows that the sodium intake of the Brazilian population is, on average, above $3200 \mathrm{mg}$ of sodium per day, as against the daily World Health Organization recommendation of sodium consumption of $2000 \mathrm{mg}$ of sodium a maximum per day $(5 \mathrm{~g}$ of salt) (Instituto Brasileiro de Geografia e Estatística [IBGE], 2011). This implies that the Brazilian ingests about $37.5 \%$ more than the recommended limit (Buzzo et al., 2014).
Excess sodium intake is the principal reason for the development of hypertension, one of the major risks for the onset of cardiovascular diseases and the main global cause of death (Kloss, Meyer, Graeve, \& Vetter, 2015) and therefore government expenditure linked to health (Buzzo et al., 2014). Evidence from studies suggest that if the average daily salt intake in the American population is reduced by $400 \mathrm{mg}$ it can prevent up to 28,000 NCD-related deaths per year and save $\$ 6$ billion in the annual public health care expenditure (Bibbins-Domingo et al., 2010).

Besides, a balanced diet with wise consumption of proteins, fibers and micronutrients accompanied by lowered sodium intake will be highly beneficial in decreasing the hypertension-related mortality levels (Oliveira et al., 2013). An individual with arterial hypertension is recommended to restrict the intake of food such as meat sausages because of the high sodium content (Buzzo et al., 2014).

On a global scale, most countries choose to implement voluntary agreements; however, seven countries (Paraguay, Belgium, Bulgaria, Greece, Hungary, Holland and Portugal) have implemented legislation for particular foods and only two countries (Argentina and South Africa) have done the same for various foods. This raises the issue of the role played by the food industries as being among the major factors of differentiation between the initiatives to reduce the salt levels in foods in different countries (Webster et al., 2014).

South Africa, in 2013, was the first country to pass comprehensive and mandatory legislation to reduce the sodium concentrations in a wide variety of processed 
food categories. The legislation that was actually enforced in 2016 has set restrictions on the maximum permissible sodium levels in commonly consumed food products, including bread, breakfast cereals, margarines, meat products, snacks and soups. Researchers monitored the decreasing the sodium levels during a one-year period preceding the date of implementing this legislation. From the results it appeared that the sodium levels of two-thirds of the foods covered had already satisfied the target that had been set (Peters et al., 2017). However, a study done in Brazil on the sodium content in industrialized foods for children reports that above $30 \%$ of the categories (corn snacks, stuffed cookies, fresh bread and cereals) failed to comply with the 2014 target of sodium reduction (Teixeira, 2018).

Another brazilian study estimated the sodium concentration in cheeses and their compliance with the voluntary agreement. The authors reported that $77.8 \%$ of the brands failed to satisfy the limit established for sodium reduction agreed upon by the Ministry of Health and Brazilian Association of Food Industries, making allowances for a period for adaptation (Ugalde, Mello, Centenaro, \& Furlan, 2019).

Therefore, while it is evident that campaigns and voluntary agreements are in place in order to lower the sodium concentration in the industrialized products, there continue to be foods with high sodium concentrations, particularly in the meat derivatives, as shown in the present work.

This leads us to consider establishing a legal device with restrictive values of added sodium during the processing of these foods, with the goal of supporting the control and inspection of the products that the Brazilian population consumes. This will guarantee the supply of healthy foods and, thus, decrease the number of diseases and deaths linked to excessive sodium consumption, to promote better public health in Brazil.

\section{Conclusion}

The sodium concentration in meat products revealed that some brands failed to standardize the quantity of the ingredient used during the formulation. A substantial proportion of the companies have failed to comply with RDC 360/2003 and their products possessed sodium in levels which crossed the legislation-determined tolerance limit. Besides, more than one third of the brands assessed were observed to have failed to satisfy the sodium reduction target agreed upon by the Ministry of Health and Brazilian Association of Food Industries. The italian salami had the highest average sodium content. Therefore, the establishment of voluntary agreements alone does not guarantee success in attaining total adequacy of sodium level control in meat products because industrialized products containing high sodium concentrations continue to be available in the market.

\section{References}

Aburto, N. J., Ziolkovska, A., Hooper, L., Elliot, P., Cappucio, F. P., \& Meerpohl, J. J. (2013). Effect of lower sodium intake on health: systematic review and meta-analyses. British Medical Journal, 346, 1326. doi: 10.1136/bmj.f1326 
Bibbins-Domingo, K., Chertow, G., Coxson, P., Moran, A., Lightwood, J., Pletcher, M., \& Goldman, L. (2010). Projected effect of dietary salt reductions on future cardiovascular disease. New England Journal of Medicine, 362(7), 590-599. doi: 10.1056/NEJMoa0907355

Buzzo, M. L., Carvalho, M. F., Arakaki, E. E., Matsuzaki, R., Granato, D., \& Kira, C. S. (2014). Elevados teores de sódio em alimentos industrializados consumidos pela população brasileira. Revista do Instituto Adolfo Lutz, 73(1), 32-39. doi: 10.18241/0073-98552014731587

Cardin, I. (2014). Acordo eficaz. Revista Nacional da Carne, 54(446), 20-28. Recuperado de https://issuu. com/btsinforma/docs/ revista_nacional da carne_ed 446

Cichoski, A. J., Zis, L. C., \& Franceschetto, C. (2009). Características físico-químicas e microbiológicas da superfície do salame tipo italiano contendo solução de lactato de potássio. Food Science and Technology, 29(3), 546-552. doi: 10.1590/ S0101-20612009000300015

Costa, F. P., \& Machado, S. H. (2010). O consumo de sal e alimentos ricos em sódio pode influenciar na pressão arterial das crianças? Ciência \& Saúde Coletiva, 15(1), 1383-1389. doi: 10.1590/S1413-812320 10000700048

Gelinski, F. R., Rodrigues, B., Hokama, L., Santos, E., Candido, C., \& Novello, D. (2015). Propriedades sensoriais e físico-químicas de patê de frango com teor reduzido de sal. Revista do Instituto Adolfo Lutz, 74(2), 122-133. Recuperado de http://www.ial. sp.gov.br/resources/insituto-adolfo-lutz/ publicacoes/rial/ 10/rial74_2_ completa/ pdf/artigosseparados/1645.pdf
Instituto Brasileiro de Geografia e Estatística (2011).Pesquisas deorçamentosfamiliares 2008-2009: análise do consumo alimentar pessoal no Brasil/IBGE, Coordenação de Trabalho e Rendimento. Rio de Janeiro, RJ: IBGE. Recuperado de https://biblioteca. ibge.gov.br/visualizacao/livros/liv50063. pdf

Kloss, L., Meyer, J., Graeve, L., \& Vetter, W. (2015). Sodium intake and its reduction by food reformulation in the European Union - A review. NFS Journal, 1, 9-19. doi: 10.1016/j.nfs.2015.03.001

Lein. 8.078, de 11 de setembro de 1990. Código de Defesa do Consumidor. Dispõe sobre a proteção do consumidor e dá outras providências. Recuperado de http://www. planalto.gov.br/ccivil_03/Leis/L8078. htm

Ministério da Agricultura, Pecuária e Abastecimento (2018). Secretaria de Defesa Agropecuária. Manual de métodos oficiais para análise de alimentos de origem animal. Brasília: MAPA. Recuperado de https://www.gov.br/agricultura/pt-br/ assuntos/laboratorios/credenciamentoe-laboratorios-credenciados/ legislacaometodos-credenciados/poa/copy3_of emtodosoficiaisparaanlisedealimentosde origemanimal1ed.rev_.pdf

Ministério da Saúde (2013). Termo de compromisso de 05 de novembro de 2013. Estabelece as metas nacionais para a redução do teor de sódio em alimentos processados no Brasil. Recuperado de https://www.abia.org.br/vsn/temp/20179 29TERMODECOMPROMISSO05nov2013. pdf

Ministério da Saúde (2018a). Monitoramento do plano de redução do sódio em alimentos processados. Relatório 
contendo avaliação das metas pactuadas para a redução do sódio em categorias prioritárias de alimentos processados. Recuperado de http://189.28.128.100/ dab/docs/portaldab/documentos/ promoção/relatorio_motitoramento_ consolidado_17_18.pdf

Ministério da Saúde (2018b). Secretaria de Vigilância em Saúde. Departamento de Análise em Saúde e Vigilância de Doenças não Transmissíveis. Vigitel Brasil 2018: Vigilância de fatores de risco e proteção para doenças crônicas por inquérito telefônico: estimativas sobre frequência e distribuição sociodemográfica de fatores de risco e proteção para doenças crônicas nas capitais dos 26 estados brasileiros e no Distrito Federal em 2018. Recuperado de https://portalarquivos2. saude.gov.br/images/ pdf/2019/julho/25/ vigitel-brasil-2018.pdf

Moratoya, E. E., Carvalhaes, G. C., Wander, A. E., \& Almeida, L. M. M. C. (2013). Mudanças no padrão de consumo alimentar no Brasil e no mundo. Revista de Política Agrícola, 22(1), 72-84. Recuperado de https://seer. sede.embrapa.br/index.php/RPA/article/ view/283

Oliveira, D. F., Coelho, A. R., Burgardt, V. C., Hashimoto, E. H., Lunkes, A. M., Marchi, J. F., \& Tonial, I. B. (2013). Alternativas para um produto cárneo mais saudável: uma revisão. Brazilian Journal of Food Technology, 16(3), 163-174. doi: 10.1590/ S1981-67232013005000021

Pardi, M. C., Santos, I. F., Souza, E. R., \& Pardi, H. S. (2001). Ciência, higiene e tecnologia da carne. Goiânia, GO: CEGRAF-UFG. Niterói: Eduff.
Peters, S., Dunford, E., Ware, L., Harris, T., Walker, A., Wicks, M.,... Neal, B. (2017). The sodium content of processed foods in South Africa during the Introduction of Mandatory Sodium Limits. Nutrients, 9(4), 404. doi: $10.3390 /$ nu9040404

Resolução RDC n² 24 de 15 de junho de 2010. Dispõe sobre a oferta, propaganda, publicidade, informação e outras práticas correlatas cujo objetivo seja a divulgação e a promoção comercial de alimentos considerados com quantidades elevadas de açúcar, de gordura saturada, de gordura trans, de sódio, e de bebidas com baixo teor nutricional. Diário Oficial da União, Brasília. Recuperado de https:// www.gov. br/agricultura/pt-br/assuntos/ inspecao/produtos-vegetal/legislacao-1/ biblioteca-de-normas-vinhos-e-bebidas/ resolucao-rdc-no-24-de-15-de-junhode-2010.pdf

Resolução RDC no 360 de 23 de dezembro de 2003. Aprova Regulamento Técnico sobre Rotulagem Nutricional de Alimentos. Diário Oficial da União, Brasília. Recuperado de http:// bvsms.saude.gov.br/bvs/saudelegis/ anvisa/2003/rdc0360_23_12_2003. htmI\#: : text=Considerando $\% 20$ a \% 20 n e cessidad e \% 20 d o \% 20 constante,prote\%C3\%A7\%C3\%A3०\%20 \%С3\%A0\%20sa\%C3\%BAde\%20da\%20 popula\%C3\%A7\%C3\%A3०\%3B\&tex $\mathrm{t}=1 \% \mathrm{C} 2 \% \mathrm{BA} \% 20 \mathrm{Aprovar} \% 200 \% 20$ Regulamento\%20T\%C3\%A9cnico,Art

Ribeiro, V., Ribeiro, M., Vasconcelos, A., Andrade, S., \& Stamford, T. L. (2013). Processed foods aimed at children and adolescents: sodium content, adequacy according to the dietary reference intakes 
and label compliance. Revista de Nutrição, 26(4), 397-406. doi: 10.1590/S141552732013000400002

Teixeira, A. (2018). Sodium content and food additives in major brands of Brazilian children's foods. Ciência \& Saúde Coletiva, 23(12), 4065-4075. doi: 10.1590/1413812320182312.21812016

Triola, M. F. (2008). Introdução à estatística. Rio de Janeiro, RJ: LTC.

Ugalde, F., Mello, K., Centenaro, G., \& Furlan, V. J. (2019). Sodium content in cheeses: suitability to the voluntary agreement and labeling. Ciência Animal Brasileira, 20, 1-13. doi: 10.1590/1809-6891v20e55176
Webster, J., Trieu, K., Dunford, E., \& Hawkes, C. (2014). Target Salt 2025: a global overview of national programs to encourage the food industry to reduce salt in foods. Nutrients, 6(8), 3274-3287. doi: 10.33 90/ nu6083274

Wyness, L., Butriss, J. L., \& Stanner, S. A. (2011). Reducing the population's sodium intake: the UK Food Standards Agency's salt reduction programme. Public Health Nutrition, 15(2), 254-261. doi: 10.1017/ S1368980011000966

Zanardi, E., Ghidini, S., Conter, M., \& laneri, A. (2010). Mineral composition of italian salami and effect of $\mathrm{NaCL}$ partial replacemente on compositional, physicochemical and sensory parameters. Meat Science, 86(3), 742-747. doi: 10.1016/j. meatsci.2010.06.015 
